\section{Japan vacillates over SSC}

\section{Tokyo}

JAPANESE Prime Minister Kiichi Miyazawa has again demonstrated Japan's unwillingness to respond decisively to US requests for support of the Superconducting Super Collider (SSC).

Last week, in a summit meeting with President George Bush in Tokyo, Miyazawa agreed only to establish a joint US-Japan working group to study how Japan might participate in the SSC. This move, which postpones any decision on financial support until at least the end of this year, came despite widespread expectation in the past few weeks that Miyazawa would promise to contribute to the SSC (see Nature 355, 8; 2 January 1992). A few months ago, Japan's sciencerelated ministries and agencies made it clear they cannot support the SSC out of their limited budgets, but the possibility of Miyazawa committing Japan to the project was left open.

Japan's vacillation over the SSC draws attention once again to the weakness of Japan's political leadership. The recent past is strewn with similar cases. For example, both Miyazawa and his predecessor Toshiki Kaifu have made repeated attempts to set up a peace-keeping force in Japan to participate in United Nation activities, but to no avail. Miyazawa then tried unsuccessfully to introduce new taxes to fund international activities, such as the SSC. Even Yasuhiro Nakasone, who was considered one of Japan's strongest prime ministers in the postwar period, took three years to launch his pet project, the Human Frontier Science Program, and even then it was only a fraction of the size originally intended.

In the case of the SSC, the bureaucrats in the Japanese government are in large part opposed to contributing, and there is little support in the academic community, but Japan was under strong political pressure to make Bush's visit to Tokyo a success. And Miyazawa apparently wanted to contribute to the SSC to ease pressure on other trade issues such as automobiles and rice. But in the final hour, he did not.

The decision to form a working group leaves everything up in the air. But one senior government official remarks that it will at least allow Japan to wait and see if Bush, a key backer of the SSC, is reelected this year.

David Swinbanks
President Bush talks with Japanese Prime Minister Miyazawa.

\title{
South Korea commits funds
}

Tokyo

THE South Korean government has launched a major effort to become a technological power rivalling Japan and leading Western nations.

The government has set aside more than $\$ 160$ million (121,000 million won) in fiscal year 1992 for the first year of the 'Highly Advanced National Project', more commonly known as the 'G-7 Project' after the G-7 group of nations (United States, Japan, Canada, the United Kingdom, France, Italy and Germany) that South Korea hopes to emulate. South Korea's technology-related ministries hope to spend more than $\$ 3,000$ million on the project during the next ten years with a matching investment from industry (see Nature 354, 176; 21 November 1991).

The budget for 1992 and projections to 2001 (see table) show that South Korea plans investment in the development of next-generation integrated circuits, an area in which it already holds considerable expertise. Development of computerized manufacturing systems, an integrated services and data network, biotechnology, and next-generation transportation systems are each expected to receive support of several hundred million dollars during the next decade from both government and industry.

South Korea, after a period of rapid industrial growth after the Korean war, is now faced with high inflation, large trade deficits and rising labour costs. The government says that the only way forward is to develop value-added high-technology products, but the population of trained scientists and engineers in South Korea is still limited, although growing rapidly. So the Ministry of Science and Technology, which controls the largest share of the G-7 budget, hopes to establish international research and development projects on which it is prepared to spend 5-20 per cent of its funds. The government also plans to allow foreign researchers to participate in national projects, in much the same way as Japan has recently opened up its government-industry research to foreign participation.

The G-7 project is the first attempt by South Korea to coordinate research by all the various technology-related ministries and agencies. In the past, lack of coordination has led to overlap of research investments, while individual budgets for each ministry have been too small for them to undertake large projects. Much of the research will be carried out by the Korea Institute of Science and Technology in Seoul and other institutes affiliated with the Ministry of Science and Technology. But the new Korea Academy of Industrial Technology under the Ministry of Trade and Industry will also play a key role in coordinating the near-market research by government laboratories, universities and industry.

David Swinbanks

\section{BUDGET FOR SOUTH KOREAN G-7 PROJECT}

thousand million won

Products Technology Development: Highly integrated semiconductors Integrated Services and Data Network High Definition Television

Electrical vehicle

Intelligent computer

Medicines and agricultural agents

Advanced production systems

SUB-TOTAL

1992

by 2001

Fundamental Technology Development:

Advanced materials

Next-generation transport systems

Biotechnology

Environmental technology

New energy resources

New atomic reactor

Human interface technology

SUB-TOTAL

$\begin{array}{rr}15 & 365 \\ 20 & 250 \\ 26 & 113 \\ 3 & 72 \\ 3 & 115 \\ 8 & 136 \\ 7 & 257 \\ 83 & 1308\end{array}$

GRAND TOTAL

$\begin{array}{rr}4 & 117 \\ 7 & 209 \\ 5 & 241 \\ 7 & 195 \\ 10 & 128 \\ 2 & 23 \\ 2 & 40 \\ 38 & 954 \\ & \\ 121 & 2262\end{array}$

$\$ 1=$ approximately 750 won

Note above figures are for all government ministries and agencies but most of the allocations are for the Ministry of Science and Technology, the Ministry of Trade and Industry, the Ministry of Energy and Resources, and the Ministry of Communications 